\begin{tabular}{cc|c}
\hline Tar. Bil. Der. & Journal of Agricultural Sciences \\
& $\begin{array}{c}\text { Dergi web sayfası: } \\
\text { www.agri.ankara.edu.tr/dergi }\end{array}$ & Journal homepage: \\
& www.agri.ankara.edu.tr/journal
\end{tabular}

\title{
Genç Elma Ăgaçlarının Vejetatif Gelişim, Meyve Verimi ve Kalitesi Üzerine Farklı Sulama Programlarının Etkileri
}

\author{
Erdal DAŞCI ${ }^{a}$, Sebahattin KAYA ${ }^{\mathrm{b}}$, Salih EVREN ${ }^{\mathrm{a}}$, Hasbi YILMAZ ${ }^{\mathrm{c}}$, Mesut Cemal ADIGÜZEL ${ }^{\mathrm{a}}$ \\ ${ }^{a}$ Doğu Anadolu Tarımsal Araştırma Enstitüsü, 25090, Aziziye, Erzurum, TÜRKIYE \\ ${ }^{\boldsymbol{b}}$ Bingöl Üniversitesi, Ziraat Fakültesi, Biyosistem Mühendisliği Bölümü, 12000, Bingöl, TÜRKIYYE \\ ${ }^{c}$ Atatürk Bahçe Kültürleri Merkez Araştırma Enstitüsü, 77102, Yalova, TÜRKIYYE
}

\section{ESER BILGISII}

Araştırma Makalesi

DOI: 10.1501/Tarimbil_0000001382

Sorumlu Yazar: Sebahattin KAYA, E-posta: sebahattinkaya@yahoo.com, Tel: +90 (426) 2160012

Geliş Tarihi: 18 Eylül 2014, Düzeltmelerin Gelişi: 01 Şubat 2015, Kabul: 02 Şubat 2015

\section{ÖZET}

$\mathrm{Bu}$ araştırma, genç elma ağaçlarının; ağaç gelişimi, meyve verim ve kalitesi üzerine farklı sulama programlarının etkilerini araştırmak için 2000-2007 yılları arasında Iğdır Ovası koşullarında yapılmıştır. Sulama programları, 90 cm 'lik toprak katmanındaki mevcut nemin, farklı zaman aralıklarında (S1: 7 gün, S2: 14 gün, S3: 21 gün ve S4: 28 gün) tarla kapasitesine getirilmesi şeklinde uygulanmıştır. Araştırmada, Golden Delicious (GD), Starking Delicious (SD) ve Granny Smith (GS) olmak üzere MM 106 anacı üzerine aşılanmış 3 farklı elma çeşidi ve ağaç altı mikro yağmurlama sulama yöntemi kullanılmıştır. Ağaç gelişimi ile meyve verim ve kalitesi üzerine sulama programlarının etkisi istatistiksel olarak önemsiz olmuştur. İstatistiksel olarak önemli farklılıklar, genellikle, yıllar ve çeşitler arasında elde edilmiştir. Yılların ortalaması olarak; GD çeşidinde ağaç gelişim ve ağaç başına meyve verim değerleri $\left(13.9 \mathrm{~cm}^{2}\right.$ $\mathrm{y}^{-1}{ }^{-1}$ ve $60.3 \mathrm{~kg}_{\text {ağaç }}$ ), GD ve SD çeşitlerinde birim gövde kesit alanına düşen meyve verimi (her iki çeşit için de $0.49 \mathrm{~kg}$ $\left.\mathrm{cm}^{-2}\right)$ ve SD çeşidinde birim taç hacmine düşen meyve verimi $\left(7.4 \mathrm{~kg} \mathrm{~m}^{-3}\right)$ diğer çeşitlerinkinden daha yüksek olmuştur. GS çeşidinde asitlik ve sertlik değerleri (\% 1.18 ve $\left.6.3 \mathrm{~kg} \mathrm{~cm}^{-2}\right)$ ve GD çeşidinde suda çözünebilir kuru madde değeri (\% 12.2) diğer çeşitlerinkinden daha yüksek olmuştur. Çeşitlerin tamamında, en yüksek su kullanım etkinliği ve sulama suyu kullanım etkinliği değerleri S4 sulama programından elde edilmiştir. Sonuç olarak, Iğdır Ovası koşullarında, su tasarrufu için, su kullanım etkinliği en yüksek olan S4 sulama programının uygulanmasının uygun olacağı kanaatine varılmıştır.

Anahtar Kelimeler: Golden delicious; Starking delicious; Granny smith; Verim; Kalite; Sulama planlaması; Iğdır ovası

\section{Effects of Different Irrigation Regimes on Vegetative Growth, Fruit Yield and Quality of Young Apple Trees}

\section{ARTICLE INFO}

Research Article

Corresponding Author: Sebahattin KAYA, E-mail: sebahattinkaya@yahoo.com, Tel: +90 (426) 2160012

Received: 18 September 2014, Received in Revised Form: 01 February 2015, Accepted: 02 February 2015 


\begin{abstract}
This study was carried out to investigate the effects of different irrigation regimes on the vegetative growth, fruit yield and quality of young apple trees from 2000 to 2007 year in Igdir Plain conditions. Irrigation regimes were applied by increasing the available water at $90 \mathrm{~cm}$ depth soil profile to field capacity in different time intervals (S1: 7 days, S2: 14 days, S3: 21 days and S4: 28 days). Three apple varieties grafted on MM106 rootstock (Golden Delicious, GD; Starking Delicious, SD; and Granny Smith, GS) and under-tree micro sprinkler irrigation method was used in this study. Effects of irrigation regimes on vegetative growth, fruit yield and quality were not statistically significant. Statistically significant differences were generally obtained among years, and cultivars. The average values of vegetative growth and fruit yield per tree of the GD $\left(13.9 \mathrm{~cm}^{2}\right.$ year-1 and $\left.60.3 \mathrm{~kg}^{-1} \mathrm{tree}^{-1}\right)$, fruit yield per unit trunk cross - sectional area of the GD and the $\mathrm{SD}\left(0.49 \mathrm{~kg} \mathrm{~cm}^{-2}\right.$ for both cultivars), and fruit yield per unit crown volume of the SD $\left(7.4 \mathrm{~kg} \mathrm{~m}^{-3}\right)$ were more than those of other cultivars for the experimental years. Titrable acidity and pulp hardness of the GS $\left(1.18 \%\right.$ and $\left.6.3 \mathrm{~kg} \mathrm{~cm}^{-2}\right)$, and total solids soluble in the water for the GD $(12.2 \%)$ was more than other cultivars. The highest water use efficiency, and irrigation water use efficiency were obtained from the S4 irrigation regime for all the cultivars. Consequently, the S4 irrigation regime to have the highest water use efficiency should use to conserve the water for the cultivation of apple in Igdir Plain conditions.
\end{abstract}

Keywords: Golden delicious; Starking delicious; Granny smith; Yield; Quality; Irrigation scheduling; Igdir plain

(C) Ankara Üniversitesi Ziraat Fakültesi

\section{Giriş}

Verim ve kalitesi yüksek ürün yetiştirmek için yeterli miktarda suyun uygun zamanda ve en uygun yöntemle verilmesi gerekir. $\mathrm{Bu}$ amaca, bitkilerin farklı gelişme dönemlerinde suyun bitki gelişimi ve verimi üzerindeki etkisinin iyi bilinmesi ile ulaşılabilir. Bu bakımdan ekonomik ve uygulanabilir sulama programlarına gereksinim duyulmaktadır. Son yıllardaki gelişmeler ve yöresel uygulamalardaki yenilikler, yeni sulama programlarının oluşturulmasını gerektirmektedir.

Bitkisel üretimi artırmak için eksik suyun tamamlanması yanında, sulama suyunun uygulanma yöntemi de önemlidir. Ağaç altı mikro yağmurlayıcılar ile ihtiyaç duyulan su kolaylıkla verilebileceği gibi bu sulama yöntemi ile türdeş su dağılımı sağlandığından, üründe önemli artışlar sağlanmaktadır. Ağaç altı mikro yağmurlama sulama yönteminin, yaprağını döken meyve ağaçlarının sulanmasında kullanımı son yıllarda yaygınlaşmıştır. Anılan sistemin damla ve yüzey sulama sistemlerine göre; düşük bakım giderleri, bir kaynaktan daha geniş 1slatma alanı sağlaması, seyrek sulama aralıklarından dolayı daha iyi yabancı ot kontrolü sağlaması, daha az tıkanıklık oluşması ve tıkanma probleminin kolay anlaşılması gibi üstünlükleri vardır (Fereres \& Goldhamer 1990). Bu sulama yönteminde, bitki besin elementlerinin kökler tarafindan alındığı 1slatılan toprak hacmi arttığı için, özellikle kumlu topraklarda yetiştirilen meyve ağaçlarında kullanımı çok önemlidir. Ayrıca ticari gübrelerin, anılan sistemle birlikte verilebilmesi, onun bir diğer üstün yanını oluşturmaktadır (Yazar \& Tekinel 1989).

$\mathrm{Bu}$ çalışmada, yüksek sulama randımanına sahip ağaç altı mikro yağmurlama sulama yönteminin, yeni kurulmuş elma bahçelerinin sulanmasında kullanılma olanakları ve farklı sulama programlarının genç elma ağaçlarının vejetatif gelişme, meyve verim ve kalitesi üzerine olan etkileri araştırılmıştır.

\section{Materyal ve Yöntem}

\subsection{Materyal}

Araştırma, Iğdır Ovasında yer alan Toprak ve $\mathrm{Su}$ Kaynakları Araştırma İstasyonu arazisinde 1999 y1lında kurulmuş olan elma bahçesinde, 2000-2007 yılları arasında yürütülmüsstür. Iğdır Ovas1, Doğu Anadolu Bölgesinde $44^{\circ} 49^{\prime}$ ve $45^{\circ}$ $31^{\prime}$ doğu boylamları ile $39^{\circ} 03^{\prime}$ ve $40^{\circ} 03^{\prime}$ kuzey enlemleri arasında yer almaktadır. Ovanın denizden 
yüksekliği ortalama 850 m'dir. Uzun yıllık verilere göre; ortalama yağış miktarı $255.7 \mathrm{~mm}$ ve yıllık ortalama sicaklık $12.1{ }^{\circ} \mathrm{C}$ 'dir. Oransal nem yillık ortalama olarak \% 55'dir. Araştırmanın yürütüldüğü yıllarda bitki yetişme döneminde kaydedilmiş yağ 1 ş değerleri Çizelge 1'de verilmiştir.

Araştırmada, MM106 yarı bodur anaçları üzerine aşılanmış üç ayrı elma çeşidi kullanılmıştır. Söz konusu çeşitler, Golden Delicious (GD), Starking Delicious (SD) ve Granny Smith (GS) olup, mevcut çeşitler arasında tozlaşma problemi yoktur. Deneme bahçesi, ağaçların sıra üzeri ve sıra arası mesafeleri 3 m x 4 m olarak 1999 yilında tesis edilmiştir.

Araştırmanın yürütüldüğü topraklar ovanın genelini tanımlayacak karakterde olup killi-tın yapıda, derin, orta kireçli, hafif bazik reaksiyonlu, organik maddece fakir, fosfor durumu az ve potasyum durumu çok fazla özellik göstermektedir. Toprakların su alma hızı $6.9 \mathrm{~cm} \mathrm{~h}^{-1}$ olarak belirlenmiştir. Araştırma yeri topraklarına ait bazı fiziksel analiz sonuçları Çizelge 2 'de verilmiştir.

İstasyonda içme suyu olarak kullanılmakta olan yeraltı suyu, bu araştırmada sulama suyu olarak kullanılmıştır ve tuzluluk açısından 2. sınıf, sodyum içeriği açısından 1. sınıf olduğu (T2A1) belirlenmiştir.
Parselleri ağaç altı mikro yağmurlama sulama yöntemi ile sulamak için her parsele (her ağaç sırasına) $32 \mathrm{~mm}$ dış çaplı 1 adet PE lateral boru hattı yerleştirilmiş ve başlangıç noktasına küresel vana takılmıştır. Lateral hatlar üzerine iki ağacın orta noktasına gelecek şekilde $3 \mathrm{~m}$ aralıklarla mini yağmurlama başlıkları yerleştirilmiştir. Yağmurlama başlıklarının basıncı test edilmiş olup, test sonucunda söz konusu başlıkların 1.5 atü çalışma basıncındaki debileri $40 \mathrm{~L} \mathrm{~h}^{-1}$, ıslatma yarı çapı ise $1.5 \mathrm{~m}$ ve dolayısıyla yağmurlama hızı $6 \mathrm{~mm}$ $\mathrm{h}^{-1}$ olarak tespit edilmiştir. Sulamalarda islatılan alan yüzdesi \% 58.9 olarak hesaplanmıştır.

\subsection{Yöntem}

Araştırma, tesadüf bloklarında bölünmüş parseller deneme desenine göre, ana parsellerde 4 sulama programı (ilk sulamayı takiben 7 günde bir sulama, $\mathrm{S} 1$; ilk sulamay1 takiben 14 günde bir sulama, S2; ilk sulamayı takiben 21 günde bir sulama, S3 ve ilk sulamayı takiben 28 günde bir sulama, S4), alt parsellerde 3 çeşit (GD, SD ve GS) olacak şekilde 3 tekerrürlü olarak düzenlenmiştir. Her alt parselde 7 ağaç bulunmaktadır. Deneme bahçesinin tesis edildiği 1999 yılında fidanların tutmaları ve eşit şartların sağlanması açısından parseldeki tüm ağaçlara eşit su uygulanmıştır.

Çizelge 1- Araştırmanın yürütüldüğü yıllarda yetişme döneminde düşen yağış değerleri (mm)

Table 1- Precipitation values in growing period of the experimental years

\begin{tabular}{lcccccccc}
\hline Ylllar & 2000 & 2001 & 2002 & 2003 & 2004 & 2005 & 2006 & 2007 \\
\hline Yağış $(\mathrm{mm})$ & 142.0 & 189.3 & 253.0 & 260.5 & 208.5 & 180.5 & 216.3 & 222.8 \\
\hline
\end{tabular}

Çizelge 2- Araştırma yeri topraklarına ilişkin bazı fiziksel analiz sonuçları

Table 2-Some physical analysis results of soils in the experimental area

\begin{tabular}{|c|c|c|c|c|c|c|c|c|c|c|c|}
\hline \multirow{2}{*}{$\begin{array}{l}\text { Toprak } \\
\text { derinliği } \\
(\mathrm{cm})\end{array}$} & \multicolumn{2}{|c|}{ Tarla kapasitesi } & \multicolumn{2}{|c|}{ Solma noktasl } & \multicolumn{2}{|c|}{ KSTK* } & \multirow{2}{*}{$\begin{array}{l}\text { Hacim } \\
\text { a } \breve{g} ı \text { rlığ } \\
\left(\mathrm{g} \mathrm{cm}^{-3}\right)\end{array}$} & \multicolumn{3}{|c|}{ Bünye analizi (\%) } & \multirow[b]{2}{*}{ Bünye } \\
\hline & $\begin{array}{l}P w \\
(\%)\end{array}$ & $m m$ & $\begin{array}{l}P w \\
(\%)\end{array}$ & $m m$ & $\begin{array}{l}P w \\
(\%)\end{array}$ & $m m$ & & Kum & Silt & Kil & \\
\hline $0-30$ & 31.5 & 115.4 & 17.4 & 63.8 & 14.1 & 51.6 & 1.22 & 29 & 35 & 36 & CL \\
\hline $30-60$ & 31.9 & 120.7 & 17.1 & 64.5 & 14.8 & 56.2 & 1.26 & 28 & 36 & 36 & CL \\
\hline $60-90$ & 35.0 & 134.3 & 17.4 & 66.8 & 17.6 & 67.5 & 1.28 & 31 & 34 & 35 & $\mathrm{CL}$ \\
\hline $90-120$ & 27.2 & 99.4 & 16.4 & 60.1 & 10.8 & 39.3 & 1.22 & 15 & 55 & 30 & $\mathrm{SiCL}$ \\
\hline
\end{tabular}

*, kullanılabilir su tutma kapasitesi 
Sulama programlarının uygulanmasina 2000 yılında başlanmıştır.

Toprak nemi, her bir sulama programı için gravimetrik yönteme göre saptanmıştır (Güngör \& Yıldırım 1989). Bu amaçla, sezon başında (Mart ayı ortasında), her ayın son gününde, yapılan her sulama öncesinde ve sezon sonunda (Ekim ay1 sonunda) topraktaki mevcut nemi belirlemek için toprak örnekleri alınmıştır. Örnekler, topraktaki nem içeriğini en iyi yansıtacak şekilde, orta blokta sulama programlarına ait parsellerde ağaçların sıra üzerinden, yağmurlama başlığı ile ağaç arasından $0-30,30-60,60-90$ ve $90-120 \mathrm{~cm}$ derinlikler aras1 toprak katmanlarından alınmıştır.

Denemede, sulamalara bitki kök bölgesindeki elverişli nem yaklaşık \% 65 'e düştüğünde başlanmış ve ilk su parsellerin tamamına eşit olarak verilmiştir. Sulamaların tamamında $90 \mathrm{~cm}$ derinliğindeki toprak katmanının nem düzeyi tarla kapasitesine getirilmiştir. Her sulamada uygulanan sulama suyu miktarı $(I, \mathrm{~mm})$, Eşitlik 1'e göre hesaplanmıştır.

$$
I=\frac{(T K-M R) \cdot \gamma_{t} \cdot D \cdot P}{100}
$$

Burada; TK, tarla kapasitesinde tutulan nem miktarı (\%); MR, sulama öncesi ölçülen nem miktarı (\%); $\gamma$ toprağın hacim ağırlı̆̆ $\left(\mathrm{g} \mathrm{cm}^{-3}\right) ; \mathrm{D}$, sslatılan toprak derinliği $(\mathrm{mm})$ ve $\mathrm{P}$, sslatılan alan oranını ifade etmektedir. Derinlik $(\mathrm{mm})$ cinsinden hesaplanan sulama suyu miktarı, parsel alanı ile çarpılarak hacim cinsinden bulunmuş ve parsel girişindeki su sayacı ile ölçülerek verilmiştir.

Bitki su tüketimi değerleri aylık ve mevsimlik olarak hesaplanmıştır. Bitki su tüketiminin (ET, mm) belirlenmesinde, Eşitlik 2 kullanılmıştır (Doorenbos \& Kassam 1988). Bu amaçla, $90 \mathrm{~cm}$ derinliğindeki toprak katmanının, yetişme sezonu içerisinde ölçülmüş olan toprak nemi değerleri kullanılmıştır.

$$
E T=P_{e}+I-D-R \mp \Delta S
$$

Burada; $\mathrm{P}_{\mathrm{e}}$, etkili yağış $(\mathrm{mm}) ; I$, uygulanan sulama suyu miktarı $(\mathrm{mm})$; D, drenajla kaybolan su miktarı (mm); R, yüzey akışla kaybolan su miktarı (mm) ve $\Delta \mathrm{S}$, toprak katmanında tutulan nem miktarındaki değişmeyi $(\mathrm{mm})$ ifade etmektedir. Araştırma süresince, bitki büyüme mevsimi boyunca düşen yağışın tamamı etkili yağış olarak alınmıştır (Güngör \& Yıldırım 1989). 90 cm derinliğindeki üst toprak katmanındaki eksik nemi tarla kapasitesine getirmek için su ölçülü olarak verildiğinden ve belirli aralıklarla nem kontrolü yapılarak $90 \mathrm{~cm}$ 'nin aşağısında nem değişimi olmadığ 1 belirlendiğinden dolayı drenajla su kaybı olmadığı anlaşılmıştır. Ayrıca, uygulanan sulama yönteminden dolayı yüzey akış oluşmadığından Eşitlik 2 yukarıda verilen bilgiler doğrultusunda değerlendirilerek Eşitlik 3 elde edilmiştir ve bu eşitliğe göre bitki su tüketimi belirlenmiştir.

$E T=P_{e}+I \mp \Delta S$

Azot kaynağ 1 olarak \% 46'l1k üre (suda eritilerek), fosfor kaynağ 1 olarak ise fosforik kullanılmıştır. Ağaç başına eşit olarak her yıl $60 \mathrm{~g}$ $\mathrm{N}, 25 \mathrm{~g} \mathrm{P}_{2} \mathrm{O}_{5}$ verilmiştir. Azot ve fosfor sıvı halde gübre tank1 vasitasiyla sulama suyu ile birlikte verilmiştir (TOPRAKSU 1978). Elma ağaçlarında, dinlenme periyodunda olmak üzere, ilk üç yılda şekil budaması, sonraki yıllarda da verim budaması yapılmıştır. Hastalık ve zararlılara karşı gerekli ilaçlamalar yapılmıştır. Yabancı ot kontrolü, sıra araları rötovatör ile $5 \mathrm{~cm}$ derinliğinde işlenerek, sıra üzerinde ise yabancı ot ilacı kullanılarak yapılmıştır.

Ağaçların vejetatif özellikleri kış dinlenme periyodunda incelenmiştir. Her alt parselde önceden belirlenmiş 3 ağaçta aşı yerinin $15-20 \mathrm{~cm}$ yukarısında ve dallanmanın başladığı yerde olmak üzere gövde kesit alanı ve aynı ağaçlarda taç genişliği (m) ve taç yüksekliği (m) belirlenmiştir (Köksal 1982; Çelik 1988). Ağaç gövde kesit alanındaki yıllık artış miktarı bakımından gövde gelişiminin hızlı olduğu 2000-2003 y1llarına ait değerler istatistiksel analize tabi tutulmuştur. Normal verimlerin alınmaya başlandığı 2003 yılından itibaren denemenin sonlandırıldığı 2007 yılına kadar ağaçların tamamında toplanan meyveler tartılarak ağaç başına meyve verimleri $\left(\mathrm{kg}\right.$ ağaç $\left.{ }^{-1}\right)$ ve dekara verimler $\left(\mathrm{kg} \mathrm{da}^{-1}\right)$ belirlenmiştir. Her parselde vejetatif ölçümlerin yapıldığı 3 ağaçta birim taç hacmine ve birim gövde kesit alanına düşen meyve verimi 
değerleri belirlenmiştir. Birim taç hacmine ve birim gövde kesit alanına düşen meyve verim değerleri, ağaçların sıra üzeri mesafeyi kapatarak vejetatif gelişmelerini tamamlamış olduğu 2005 yılı ve sonraki yıllar için, ağaç gelişim ve verim değerleri dikkate alınarak belirlenmiş ve istatistiksel olarak analiz edilmiştir. Meyve eti sertliği $6 \mathrm{~mm}$ çapında delici uca sahip penetrometre ile, suda çözünebilir toplam kuru madde miktarı süzülmemiş meyve suyunda Carl-Zeis-Abbe el refraktometresi ile doğrudan \% olarak ölçülmüştür (Karaçalı 2006). Olgunlaşmanın göstergesi olan titre edilebilir asit oranı, 1:5 oranında saf su ile seyreltilmiş meyve suyunda çözeltinin rengi gülkurusu pembe oluncaya kadar $0.1 \mathrm{~N} \mathrm{NaOH}$ çözeltisi ile titre edilerek malik asit cinsinden belirlenmiştir (Karaçalı 2006). Ağaç başına düşen meyve verimi ve yukarıda belirtilen meyve kalitesi ile ilgili değerler 2003-2007 yılları için belirlenmiş ve istatistiksel analize tabi tutulmuştur.

Su kullanım etkinliği ve sulama suyu kullanım etkinliği değerleri, 2003-2007 yılları ortalaması olarak, her bir sulama programında her bir çeşit için elde edilen dekar başına meyve verimleri, bitki su tüketimi ve sulama suyu değerlerine bölünmek suretiyle elde edilmiştir.

Ağaç gelişimi, meyve verimi ve kalitesine ait verilerin, tesadüf bloklarında bölünmüş parseller deneme desenine göre öncelikle yıllık olarak varyans analizleri yapılmıştır. Daha sonra varyansların homojenliği kontrol edilmek suretiyle, yıl birleştirmesi yapılarak toplu varyans analizleri yapılmıştır (Yurtsever 1984). Ağaç başına düşen verim değerleri, varyansların homojen olmaması nedeniyle toplu analize tabi tutulmamıştır. Varyans analizleri JMP 7 yazılımı kullanılarak $\mathrm{F}$ testine göre \% 5 lik hata sınırı dikkate alınarak yapılmıştır (SAS 2007). İstatistiksel analizlerde \% cinsinden ve 0-1 aralığında olan desimal değerlerin dönüşümü yapılmıştır. Varyans analizi sonuçlarına göre ortaya çıkan farklılıklar \% 5 hata sınırında LSD testi esas alınarak gruplandırılmıştır (Yurtsever 1984; SAS 2007).

\section{Bulgular ve Tartışma}

2000-2007 yıllarına ait mevsimlik sulama suyu miktarı ve su tüketim değerleri Çizelge 3'de verilmiştir. Uygulanan mevsimlik sulama suyu miktarları (yılların ortalaması olarak), sulama programları için 286-524 mm, ölçülen bitki su tüketim değerleri ise 504-735 $\mathrm{mm}$ arasında olmuştur. Bu konuda yapılmış çalışmalarda, elma ağaçlarına verilen sulama suyu miktarları ve bitki su tüketimleri; Kıvanç (1991) tarafından 495-814 mm, Köksal et al (1999) tarafından 609-733 mm, Günbatılı \& Demirören (1980) tarafindan 547-845 mm ve Güngör \& Kanburoğlu (1978) tarafindan 531-920 mm olarak tespit edilmiştir. Çizelge 3`e göre, S1 sulama programına oranla; S2, S3 ve S4 sulama programlarında sirasiyla $\% 26, \% 42$ ve $\% 45$ daha az sulama suyu kullanılmıştır. Bitki su tüketimleri ise, S1 sulama programına oranla S2, S3 ve S4 sulama programlarında sirasiyla \% 17 , $\% 28$ ve \% 31 daha az olmuştur. Programların su tüketimleri arasındaki bu farklılık, sulamaların yapılma sıklığından kaynaklanmıştır ve toprak katmanında oluşan farklı nem düzeyleri, bitkilerin farklı miktarlarda su kullanımına neden olmuştur. Farklı sulama programlarının, sulamalardan 1 gün önceki $90 \mathrm{~cm}$ derinlikteki toprak katmanının su içeriğine olan etkileri 2001, 2004 ve 2007 yılları için (araştırmanın başlangıç, orta ve son yıllarını karşılayacak şekilde) Şekil 1-3'de verilmiştir.

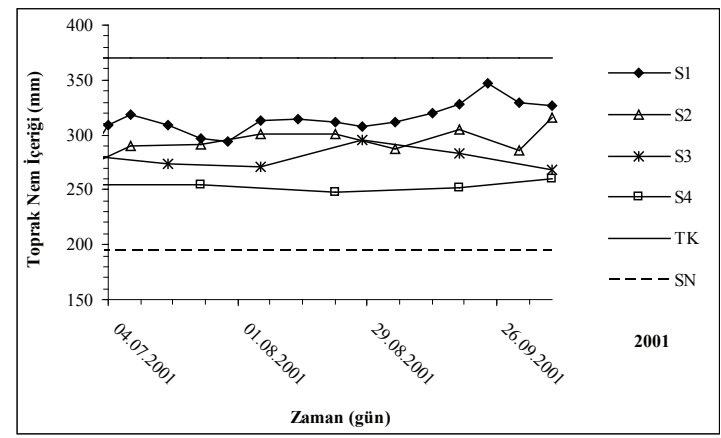

TK, tarla kapasitesi; SN, solma noktası

Şekil 1- 2001 yılı için sulama programlarının toprak nem içeriğine olan etkileri

Figure 1-Effects of irrigation regimes on soil moisture content for 2001 
Çizelge 3- Uygulanan sulama suyu miktarları ve ölçülen su tüketim değerleri

Table 3-Amounts of irrigation water applied and values of evapotranspiration determined

\begin{tabular}{|c|c|c|c|c|c|c|c|c|c|}
\hline Yillar & $\begin{array}{c}\text { Sulama } \\
\text { programı }\end{array}$ & $\begin{array}{c}\text { Sulama } \\
\text { aralığı } \\
\text { (gün) }\end{array}$ & $\begin{array}{c}\text { Sulama } \\
\text { suyu } \\
\text { miktarl } \\
(\mathrm{I}, \mathrm{mm})\end{array}$ & $\begin{array}{l}\text { Bitki su } \\
\text { tüketimi } \\
(E T, \mathrm{~mm})\end{array}$ & Yillar & $\begin{array}{c}\text { Suama } \\
\text { programı }\end{array}$ & $\begin{array}{c}\text { Sulama } \\
\text { aralığgl } \\
\text { (gün) }\end{array}$ & $\begin{array}{l}\text { Sulama } \\
\text { suyu } \\
\text { mikttarl } \\
(\mathrm{I}, \mathrm{mm})\end{array}$ & $\begin{array}{l}\text { Bitki su } \\
\text { tüketimi } \\
\text { (ET, mm) }\end{array}$ \\
\hline \multirow{4}{*}{2000} & S1 & 7 & 455 & 565 & \multirow{4}{*}{2005} & $\mathrm{~S} 1$ & 7 & 450 & 590 \\
\hline & S2 & 14 & 310 & 454 & & S2 & 14 & 350 & 485 \\
\hline & S3 & 21 & 272 & 369 & & S3 & 21 & 287 & 444 \\
\hline & S4 & 28 & 266 & 358 & & S4 & 28 & 266 & 445 \\
\hline \multirow{4}{*}{2001} & S1 & 7 & 529 & 673 & \multirow{4}{*}{2006} & S1 & 7 & 580 & 892 \\
\hline & S2 & 14 & 385 & 539 & & S2 & 14 & 422 & 744 \\
\hline & S3 & 21 & 283 & 484 & & S3 & 21 & 345 & 686 \\
\hline & S4 & 28 & 282 & 483 & & S4 & 28 & 297 & 570 \\
\hline \multirow{4}{*}{2002} & S1 & 7 & 663 & 886 & \multirow{4}{*}{2007} & S1 & 7 & 666 & 952 \\
\hline & S2 & 14 & 439 & 663 & & S2 & 14 & 475 & 769 \\
\hline & S3 & 21 & 340 & 579 & & S3 & 21 & 355 & 659 \\
\hline & S4 & 28 & 315 & 577 & & S4 & 28 & 313 & 600 \\
\hline \multirow{4}{*}{2003} & S1 & 7 & 392 & 615 & \multirow{4}{*}{$\begin{array}{l}2000- \\
2007 \\
\text { Ort. }\end{array}$} & S1 & 7 & 524 & 735 \\
\hline & S2 & 14 & 353 & 593 & & S2 & 14 & 386 & 612 \\
\hline & S3 & 21 & 277 & 492 & & S3 & 21 & 306 & 531 \\
\hline & S4 & 28 & 264 & 473 & & S4 & 28 & 286 & 504 \\
\hline \multirow{4}{*}{2004} & S1 & 7 & 454 & 706 & \multirow{4}{*}{$\begin{array}{l}2003- \\
2007 \\
\text { Ort. }\end{array}$} & S1 & 7 & 508 & 751 \\
\hline & S2 & 14 & 353 & 644 & & S2 & 14 & 391 & 647 \\
\hline & S3 & 21 & 290 & 535 & & S3 & 21 & 311 & 563 \\
\hline & S4 & 28 & 284 & 519 & & S4 & 28 & 285 & 522 \\
\hline
\end{tabular}

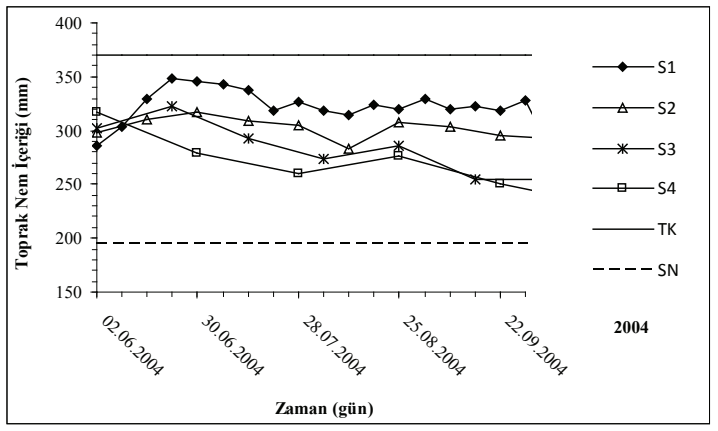

Şekil 2- 2004 yılı için sulama programlarının toprak nem içeriğine olan etkileri

Figure 2- Effects of irrigation regimes on soil moisture content for 2004

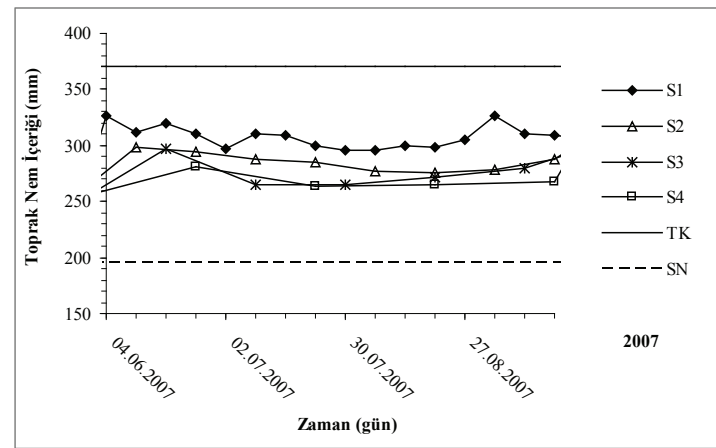

Şekil 3- 2007 yılı için sulama programlarının toprak nem içeriğine olan etkileri

Figure 3-Effects of irrigation regimes on soil moisture content for 2007 
Ağaç gövde kesit alanındaki yıllık artış miktarı bakımından yıllar arasında, istatistiksel olarak önemli farklılıklar belirlenmiştir. En yüksek artış miktarı 2003 yılında $\left(18.9 \mathrm{~cm}^{2} \mathrm{y}^{-1}{ }^{-1}\right)$, en düşük artış miktarı ise 2000 yılında $\left(7.4 \mathrm{~cm}^{2} \mathrm{y}_{1} \mathrm{l}^{-1}\right)$ elde edilmiştir. Yıllar arasındaki bu farklılığın, gelişme dönemindeki ağaçlara ait genel bir özellik olduğu kanaatine varılmıştır. Her bir yıl için ve yılların ortalaması olarak, sulama programlarının gövde kesit alanındaki yıllık artış miktarına etkisi önemsiz olmuştur. Benzer sonuçlar, Köksal et al (1999) tarafindan da elde edilmiştir. 2002 yılı hariç, her bir yıl için ve yılların ortalaması olarak çeşitler arasındaki fark önemli bulunmuştur. 2000 ve 2001 yıllarında en yüksek değerler GD çeşidinden (sırasıyla 9.1 ve $11.5 \mathrm{~cm}^{2} \mathrm{y}^{-1}{ }^{-1}$ ), 2003 yılında ise GD ve GS çeşitlerinden (sırasıyla 21.1 ve $19.3 \mathrm{~cm}^{2} \mathrm{y}_{1 l^{-1}}$ ) elde edilmiştir. Yılların ortalaması olarak en yüksek yıllık artış değeri GD çeşidinden $\left(13.9 \mathrm{~cm}^{2} \mathrm{yll}^{1-1}\right)$ elde edilmiştir. Birleştirilmiş analizlerde y1l x sulama programı ve yıl x sulama programı x çeşit interaksiyonları önemli bulunmazken, yıl x çeşit interaksiyonu ile sulama programı $\mathrm{x}$ çeşit interaksiyonları önemli bulunmuştur. Farklılıkların önemli çıktığı y1l x çeşit interaksiyonuna göre en yüksek yıllık artış değeri 2003 yılında GD çeşidinden $\left(21.1 \mathrm{~cm}^{2}\right.$ yıl ${ }^{1}$ ) elde edilmiştir (Çizelge 4). Sulama programı x çeşit interaksiyonu 2003 yılında ve birleştirilmiş analizlerde önemli çıkmıştır. 2003 yılında, en yüksek yıllık artış değeri S3 sulama programında GD çeşidinden $\left(24.3 \mathrm{~cm}^{2} \mathrm{y}^{1-1}\right)$ elde edilmiştir. Birleştirilmiş analizlerde (tüm yıllar ortalaması olarak) ise aynı istatistik grupta yer alan S1 ve S3 sulama programlarında GD çeşidi (sırasıyla 14.3 ve $\left.15.6 \mathrm{~cm}^{2} \mathrm{y}^{1-1}\right)$ en yüksek yıllık artışa sahip olmuştur (Çizelge 5).

Ağaç başına verim bakımından sadece 2004 yılında sulama programları arasındaki farklar önemli olmuştur, diğer yıllarda ise önemli olmamıştır. 2004 yılında en yüksek verim S1 sulama programından (40.5 kg ağaç ${ }^{-1}$ ) elde edilmiştir. 2005 yılı hariç, diğer yılların tamamında ağaç başına verim bakımından çeşitler arasındaki farklılık önemli olmuştur. 2003, 2004 ve 2006 yıllarında en yüksek verimler GD çeşidinden (sırasıyla 18.4, 69.4 ve $142.7 \mathrm{~kg}_{\text {ağaç-1)}}{ }^{-1}$, 2007 yılında ise GS çeşidinden $\left(84.2 \mathrm{~kg} \mathrm{ağaç}^{-1}\right)$ elde edilmiştir. Çeşitler için yıllar arasındaki verim farklılığ 1 dikkate alınarak değerlendirildiğinde, GD çeşidinde periyodisitenin etkisi açıkça görülmektedir (Çizelge 4). Sulama programı x çeşit interaksiyonu bakımından ortaya çıkan farklılıklar sadece 2005 yılında önemli olmuştur. En yüksek verim S2 sulama programında GD çeşidinden $\left(56.2 \mathrm{~kg}\right.$ ağaç $\left.^{-1}\right)$ elde edilmiştir (Çizelge 5). Orta et al (2001), Starking Delicious elma çeşidinde yüzey ve damla sulama yöntemlerinde farklı sulama programlarının verim ve kalite özelliklerine etkisinin olmadığını tespit etmişlerdir. Köksal et al (1999), elma çeşitlerinde ağaç altı mikro yağmurlama yönteminde farklı sulama programlarının, ağaç başına düşen meyve verimleri üzerine etkisinin; Starkspur Golden Delicious çeşidinde önemsiz, Starkrimson çeşidinde ise önemli olduğunu belirtmişlerdir.

Birim gövde kesit alanına düşen verim bakımından yıllar arasındaki farklılık önemli olmamıştır. Sulama programları arasındaki farklılık sadece 2007 y1lında önemli olmuştur. En yüksek verimler aynı istatistik grup içersinde yer alan S2 ve S3 sulama programlarından (sırasiyla 0.49 ve $0.47 \mathrm{~kg} \mathrm{~cm}^{-2}$ ) elde edilmiştir (Çizelge 4). Köksal et al (1999), ağaç altı mikro yağmurlama yönteminde farklı sulama programlarının, birim gövde kesit alanına düşen meyve verimleri üzerine etkisinin; Starkspur Golden Delicious ve Starkrimson çeşitlerinde önemsiz olduğunu belirtmişlerdir. 2005 yılında çeşitler arasındaki farklılık önemsiz olmasına rağmen, 2006 ve 2007 yıllarında ve yılların ortalaması olarak çeşitler arasındaki farklılık önemli çıkmıştır. 2006 yılında en yüksek verim GD çeşidinden $\left(0.84 \mathrm{~kg} \mathrm{~cm}^{-2}\right)$ elde edilmiştir. $2007 \mathrm{y}$ llında ise en yüksek verim aynı istatistik grup içerisinde yer alan SD ve GS çeşitlerinden (her iki çeşit için de $0.52 \mathrm{~kg} \mathrm{~cm}^{-2}$ ) elde edilmiştir. GD çeşidinde 2006 ve 2007 yıllarındaki bu farklılığın, yukarıda da belirtildiği gibi periyodisiteden kaynaklandığı kanaatine varılmıştır. Yılların ortalaması olarak en yüksek verim GD ve SD çeşitlerinden (her iki çeşit için de $0.49 \mathrm{~kg} \mathrm{~cm}^{-2}$ ) elde edilmiştir (Çizelge 4). Sulama programı x çeşit interaksiyonu sadece 


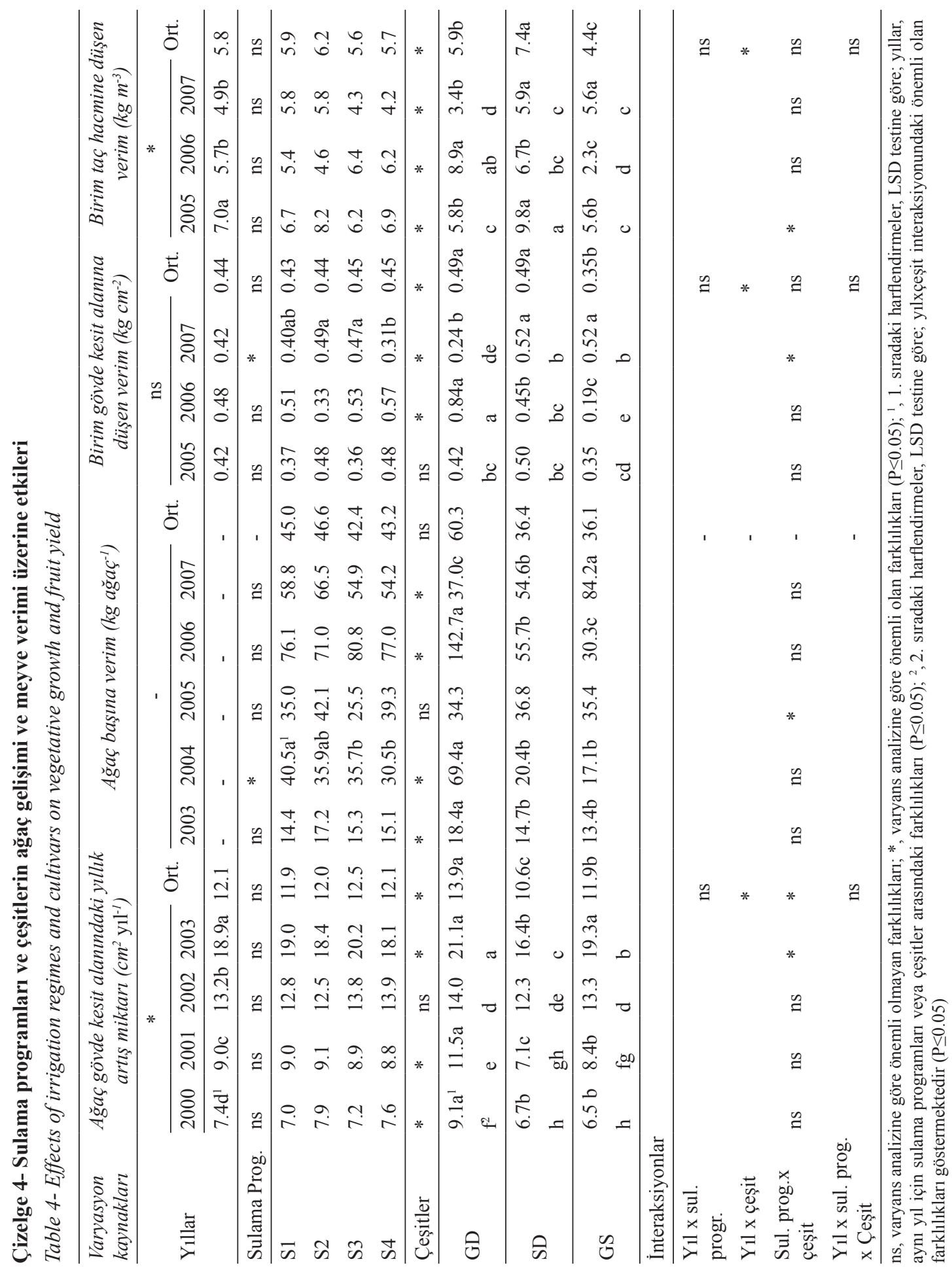

Tarım Bilimleri Dergisi - Journal of Agricultural Sciences 22 (2016) 216-228 
Çizelge 5- Ağaç gelişimi ve meyve verimi üzerine sulama programı $x$ çeşit interaksiyon etkileri

Table 5- Effects of irrigation regimexcultivar interaction on vegetative growth and fruit yield

\begin{tabular}{|c|c|c|c|c|c|c|c|c|c|c|c|c|c|c|c|}
\hline \multirow[t]{2}{*}{$\begin{array}{l}\text { Sul. } \\
\text { prog. }\end{array}$} & \multicolumn{3}{|c|}{$\begin{array}{c}\text { Gövde kesit alanındaki } \\
\text { yıllık artış } \\
(2003 \text { Yılı) }\end{array}$} & \multicolumn{3}{|c|}{$\begin{array}{c}\text { Gövde kesit alanındaki } \\
\text { ylllık artış } \\
\text { (Tüm yıllar ort.) }\end{array}$} & \multicolumn{3}{|c|}{$\begin{array}{c}\text { A ğaç başına verim } \\
(2005 \text { yll })\end{array}$} & \multicolumn{3}{|c|}{$\begin{array}{c}\text { Birim gövde kesit } \\
\text { alanına düşen verim } \\
\text { (2007 yılı) }\end{array}$} & \multicolumn{3}{|c|}{$\begin{array}{c}\text { Birim taç hacmine düşen } \\
\text { verim }(2005 \mathrm{yll})\end{array}$} \\
\hline & $G D$ & & $G S$ & $G D$ & $S D$ & $G S$ & & & & $G D$ & $S D$ & $G S$ & & & \\
\hline & & & & & & & & & & & & & & & \\
\hline & & $18.2 \mathrm{bc}$ & $18.3 b c$ & $11.6 \mathrm{cde}$ & $12.2 \mathrm{~cd}$ & $1 \mathrm{~cd}$ & & & & $0.37 \mathrm{~cd}$ & $0.65 \mathrm{ab}$ & & & & \\
\hline & & $17.0 \mathrm{c}$ & $9.3 b c$ & $15.6 \mathrm{a}$ & & & & & & & & & & & \\
\hline & $0.8 \mathrm{ab}$ & $16.4 \mathrm{c}$ & $17.2 \mathrm{c}$ & 14.1 ab & $10.6 \mathrm{e}$ & $11.6 \mathrm{cde}$ & $45.2 \mathrm{ab}$ & $33.9 \mathrm{bcd}$ & $38.8 \mathrm{abc}$ & $0.09 \mathrm{e}$ & $0.34 \mathrm{~d}$ & $0.54 \mathrm{abc}$ & 7.1 bcde & & $4.6 \mathrm{cde}$ \\
\hline
\end{tabular}

*, harflendirmeler, LSD testine göre önemli olan farklılıkları göstermektedir $(\mathrm{P} \leq 0.05)$

2007 y1lında önemli olmuştur ve en yüksek verim S3 sulama programında SD çeşidinden $\left(0.72 \mathrm{~kg} \mathrm{~cm}^{-2}\right)$ elde edilmiştir (Çizelge 5). Yıl x sulama programı ve yıl x sulama programı x çesit interaksiyonları önemli olmazken, yıl x çeşit intetraksiyonu önemli olmuştur. Yil x çeşit interaksiyonuna göre en yüksek verim 2006 y1lında GD çeşidinden $\left(0.84 \mathrm{~kg} \mathrm{~cm}^{-2}\right)$ elde edilmiştir (Çizelge 4).

Birim taç hacmine düşen verim bakımından yıllar arasındaki farklılık önemli olmuştur. En yüksek verim 2005 yllında $\left(7.0 \mathrm{~kg} \mathrm{~m}^{-3}\right)$ elde edilmiştir. Her bir yıl için ve yılların ortalaması olarak sulama programları arasında fark önemli olmamıştır. Benzer sonuçlar, Köksal et al (1999) tarafindan da elde edilmiştir. Çeşitler arasındaki farklılık, yılların tamamında ve yılların ortalaması olarak önemli olmuştur. En yüksek verimler 2005 ve 2007 yıllarında SD çeşidinden (sırasıyla 9.8 ve $5.9 \mathrm{~kg} \mathrm{~m}^{-3}$ ), 2006 yllında ise GD çeşidinden $\left(8.9 \mathrm{~kg} \mathrm{~m}^{-3}\right)$ elde edilmiştir. Yılların ortalaması olarak en yüksek verim SD çeşidinden $\left(7.4 \mathrm{~kg} \mathrm{~m}^{-3}\right.$ ) elde edilmiştir (Çizelge 4). Sulama programı $\mathrm{x}$ çeşit interaksiyonu sadece 2005 yılında önemli olmuştur ve en yüksek verim S1 sulama programında SD çeşidinden $\left(13.7 \mathrm{~kg} \mathrm{~m}^{-3}\right)$ elde edilmiştir (Çizelge 5). Yıl x sulama programı ve yıl x sulama programı x çesit interaksiyonları önemli olmazken, yıl x çeşit interaksiyonu önemli olmuştur. Y1l x çeşit interaksiyonuna göre en yüksek verim 2005 y1lında SD çeşidinden $\left(9.8 \mathrm{~kg} \mathrm{~m}^{-3}\right)$ elde edilmiş̧ir (Çizelge 4).

Titre edilebilir asitlik bakımından yıllar arasındaki farklılık önemli olmuştur. Aynı istatistik grup içerisinde yer alan 2003, 2005 ve 2007 y1llarındaki asitlik değerleri (sırasıyla \% 0.74 , $\% 0.74$ ve $\% 0.75), 2004$ ve 2006 yıllarında elde edilen asitlik değerlerinden (surasiyla \% 0.61 ve $\%$ 0.64) önemli düzeyde daha yüksek olmuştur. Sulama programları arasındaki farklılık sadece 2003 y1lında önemli olmuştur. 2003 yılında S1 sulama programından elde edilen asitlik değeri (\% 0.80), aynı istatistik grup içinde yer alan diğer sulama programlarına göre önemli derecede yüksek olmuştur (Çizelge 6). Köksal et al (1999) ve Orta et al (2001), benzer şekilde sulama programlarının titre edilebilir asitlik üzerine etkisinin önemsiz olduğunu belirtmişlerdir. Yılların ortalaması olarak sulama programları arasındaki fark önemli bulunmamıştır. Tüm yıllarda ve yılların ortalaması olarak çeşitler arasındaki farklar önemli olmuştur. Tüm yıllar ve yılların ortalaması için en yüksek asitlik değerleri GS çeşidinden (ortalama \% 1.18), en düşük asitlik değerleri ise SD çeşidinden (ortalama \% 0.38) elde edilmiştir ki bu durum olması gereken bir sonuçtur. Sulama programı $\mathrm{x}$ çeşit interaksiyonları tüm yıllarda ve yılların ortalaması olarak önemsiz olmuştur. Birleştirilmiş analizlerde yıl x sulama programı, sulama programı $\mathrm{x}$ çeşit ve yıl $\mathrm{x}$ sulama programı $\mathrm{x}$ çeşit interaksiyonları önemli bulunmamış, yıl x çeşit interaksiyonu ise önemli bulunmuştur. Y1l $\mathrm{x}$ çeşit interaksiyonunda en yüksek değer 2003 yılında GS çeşidinden (\% 1.23) elde edilmiştir (Çizelge 6).

Suda çözünebilir kuru madde (SÇKM) bakımından yıllar arasındaki farklılık önemli olmuştur. En yüksek SÇKM değerleri aynı istatistik grup içerisinde yer alan 2003 ve 2006 yıllarında 


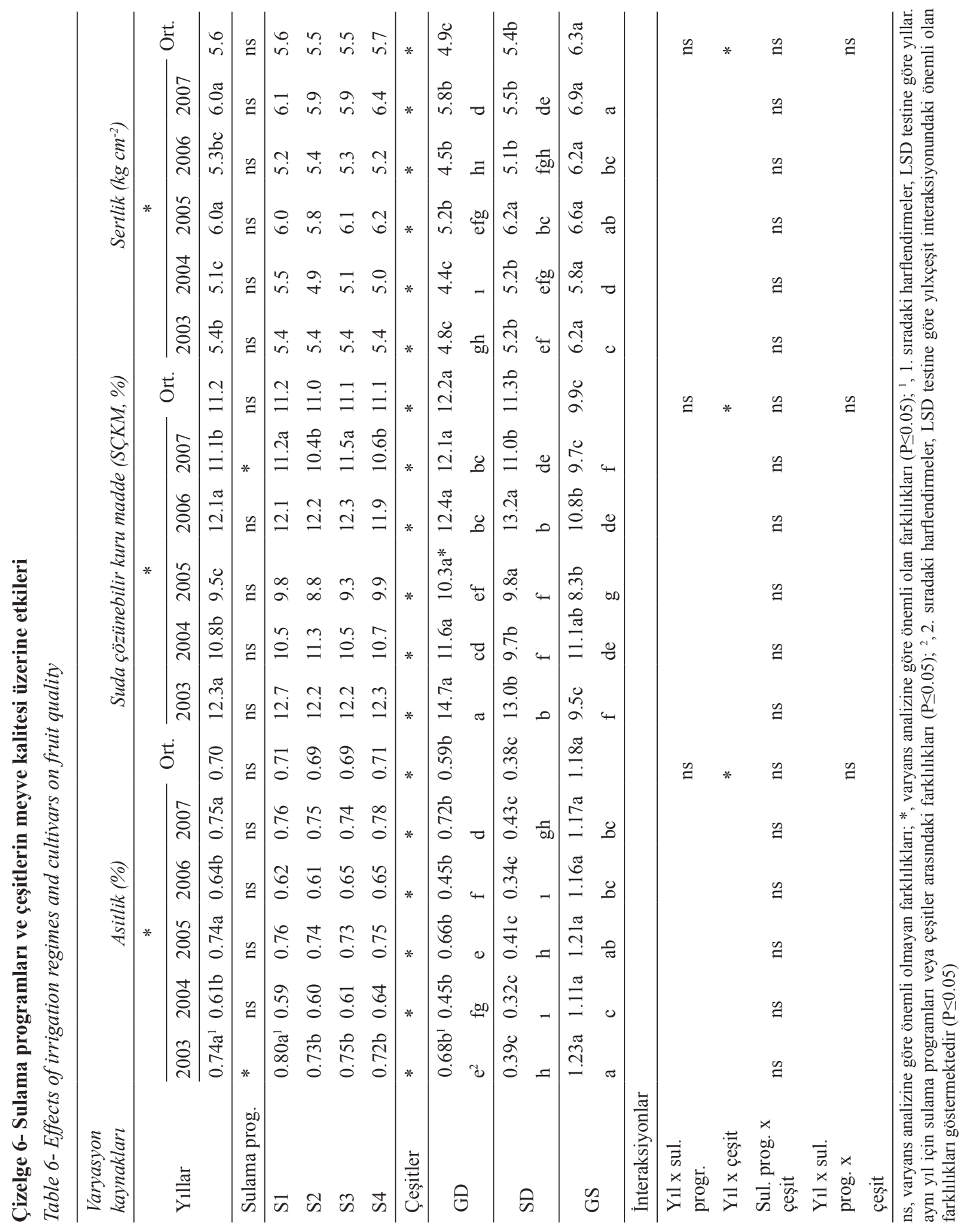


(sırasıyla \% 12.3 ve \% 12.1) elde edilmiştir. Sulama programları arasındaki farklılık sadece 2007 y1lında önemli çıkmıştır. 2007 yılında aynı istatistik grup içerisinde yer alan $\mathrm{S} 1$ ve $\mathrm{S} 3$ sulama programlarından elde edilen SÇKM değerleri (sırasıyla \% 11.2 ve $\%$ 11.5), aynı istatistik grup içinde yer alan $\mathrm{S} 2$ ve S4 sulama programlarından elde edilen değerlerden (sırasıyla \% 10.4 ve \% 10.6) daha yükssek olmuştur (Çizelge 6). Benzer şekilde, sulama programlarının, SÇKM miktarları üzerine etkisinin önemsiz olduğu, Köksal et al (1999) tarafindan da belirtilmiştir. Yılların ortalaması olarak sulama programları arasındaki fark önemsiz olmuştur. Tüm yıllarda ve yılların ortalaması olarak çeșitler arasındaki farklar önemli olmuştur. En yüksek SÇKM değerleri, 2003, 2004 ve 2007 yıllarında GD çeşidinden (sırasıyla $\% 14.7, \% 11.6$ ve $\% 12.1$ ) elde edilmiştir. 2005 ve 2006 yıllarında ise, aynı istatistik grup içerisinde yer aldıklarından dolayı, GD ve SD çeşitlerinden (2005 yılı için sırasıyla \% 10.3 ve \% 9.8, 2006 yılı için sırasıyla \% 12.4 ve \% 13.2) elde edilmiştir. Yılların ortalaması olarak en yüksek SÇKM değeri GD çeşidinden (\% 12.2) elde edilmiştir. Sulama programı $\mathrm{x}$ çeşit interaksiyonları tüm yıllarda ve yılların ortalamasına göre önemli olmamıştır. Birleştirilmiş analizlerde yılxsulama programı, sulama programı $\mathrm{x}$ çeşit ve yıl x sulama programı $\mathrm{x}$ çeşit interaksiyonları önemli bulunmamış, yıl x çeşit interaksiyonu ise önemli bulunmuştur. Y1l x çeşit interaksiyonunda en yüksek değer 2003 y1lında GD çeşidinden (\% 14.7) elde edilmiştir (Çizelge 6).

Sertlik bakımından da yıllar arasındaki farklılık önemli bulunmuştur. En yüksek sertlik değerleri, aynı istatistik grup içerisinde yer alan 2005 ve 2007 yıllarında (her iki yıl için de $6.0 \mathrm{~kg} \mathrm{~cm}^{-2}$ ) elde edilmiştir. Yılların tamamında ve birleştirilmiş analizlerde (yılların ortalaması olarak) sulama programları arasındaki farklılık önemsiz çıkmış olmasına karşın çeşitler arasındaki farklılık önemli olmuştur. En yüksek sertlik değerleri 2005 yılı haricindeki diğer yıllarda GS çeşidinden (2003, 2004, 2006 ve 2007 yılları için sırasıyla 6.2, 5.8, 6.2 ve $6.9 \mathrm{~kg} \mathrm{~cm}^{-2}$ ), 2005 yılında ise, aynı istatistik grup içerisinde yer aldıklarından dolayı, SD ve GS çeşitlerinden (sırasıyla 6.2 ve $6.6 \mathrm{~kg} \mathrm{~cm}^{-2}$ ) elde edilmiştir. Yılların ortalaması olarak en yüksek değer GS çeşidinden $\left(6.3 \mathrm{~kg} \mathrm{~cm}^{-2}\right)$ elde edilmiştir. Elde edilen bu değerler, bu konudaki bilgi ve duyusal gözlemlerle de uyuşmaktadır. Sulama programı x çeşit interaksiyonları tüm yıllarda ve yılların ortalamasına göre önemli bulunmamıştır. Birleştirilmiş analizlerde y1l x sulama programı, sulama programı x çeşit ve yıl x sulama programı x çeşit interaksiyonları önemli bulunmamış, yıl x çeşit interaksiyonu ise önemli bulunmuştur. Yıl x çeşit interaksiyonunda en yüksek değer 2007 yılında GS çeşidinden $\left(6.9 \mathrm{~kg} \mathrm{~cm}^{-2}\right)$ elde edilmiştir (Çizelge 6).

Sulama programlarının su kullanım etkinliği ve sulama suyu kullanım etkinliği değerleri Çizelge 7'de verilmiştir. Yılların ortalaması olarak, en yüksek su kullanım etkinliği ve sulama suyu kullanım etkinliği değerleri S4 sulama programından (6.62 ve 12.12 $\mathrm{kg} \mathrm{da} \mathrm{mm}^{-1} \mathrm{~mm}^{-1}$, en düşük değerler ise $\mathrm{S} 1$ sulama programından (4.99 ve $7.37 \mathrm{~kg} \mathrm{da}^{-1} \mathrm{~mm}^{-1}$ ) elde edilmiştir. Böylece, en fazla sulama suyu uygulanan sulama programinda su kullanım ve sulama suyu

Çizelge 7-Sulama programları ve çeşitlerin su kullanım etkinliği ve sulama suyu kullanım etkinliği değerleri Table 7-Values of water use efficiency, and irrigation water use efficiency for irrigation regimes and cultivars

\begin{tabular}{cllll}
\hline \multirow{2}{*}{ Sulama programı } & \multicolumn{3}{c}{ Su kullanım etkinliği ve sulama suyu kullanım etkinliği $\left(\mathrm{kg} \mathrm{da}^{-1} \mathrm{~mm}^{-1}\right)$} \\
\cline { 2 - 5 } & Golden Delicious & Starking Delicious & Granny Smith & Ortalama \\
\hline S1 & $6.36^{*}-9.40^{* *}$ & $4.25-6.28$ & $4.36-6.44$ & $4.99-7.37$ \\
S2 & $6.42-10.63$ & $5.05-8.35$ & $4.24-7.01$ & $5.24-8.66$ \\
S3 & $8.34-15.10$ & $5.24-9.49$ & $5.34-9.66$ & $6.31-11.42$ \\
S4 & $8.77-16.07$ & $5.31-9.72$ & $5.77-10.56$ & $6.62-12.12$ \\
\hline
\end{tabular}

\footnotetext{
*, su kullanım etkinliği; **, sulama suyu kullanım etkinliği
} 
kullanım etkinliği değerleri düşük, en az sulama suyu uygulanan sulama programında ise yüksek çıkmıştır. Bu durum, uygulanan sulama suyundaki artışa bağlı olarak verimin artmamasından, hatta fazla su uygulanan sulama programlarından elde edilen verimlerin, daha az su uygulanan programlardan elde edilen verimlerden daha düşük olmasından kaynaklanmıştır. Çeşitler bakımından da su kullanım etkinliği değerleri farklı olmuştur. Çeşitlerin her üçünde de en yüksek değerler S4 sulama programından, en düşük değerler GD ve SD çeşitlerinde $\mathrm{S} 1$ sulama programından, GS çeşidinde ise S2 sulama programından ve elde edilmiştir. En yüksek sulama suyu kullanım etkinliği değerleri, bütün çeşitler için S4 sulama programından, en düşük değerler ise yine tüm çeşitler için $\mathrm{S} 1$ sulama programından elde edilmiştir. Tüm sulama programları ve çeşitler dikkate alındığında, en yüksek su kullanım etkinliği ve sulama suyu kullanım etkinliği değerleri S4 sulama programında GD çeşidinden (8.77 ve $16.07 \mathrm{~kg} \mathrm{da}^{-1} \mathrm{~mm}^{-1}$ ) elde edilmiştir. En düşük su kullanım etkinliği değeri S2 sulama programında GS çeşidinden $\left(4.24 \mathrm{~kg} \mathrm{da}^{-1}\right.$ $\mathrm{mm}^{-1}$ ) ve en düşük sulama suyu kullanım etkinliği değeri ise S1 sulama programında SD çeşidinden $\left(6.28 \mathrm{~kg} \mathrm{da}^{-1} \mathrm{~mm}^{-1}\right)$ elde edilmiştir.

\section{Sonuçlar}

Farklı sulama programlarının elma ağaçlarının gelişimi, meyve verimi ve kalitesi üzerine olan etkileri genel olarak istatistikî açıdan önemsiz olmuştur. Önemli farklılıklar, genellikle, yıllar ve çeşitler arasında elde edilmiştir. Yıllar arasındaki farklılığın önemli çıkması, özellikle ağaçların genç olmasından ve dolayısıyla olgunlaştıkça gelişim ve verimlerinin artmasından kaynaklanmıştır. Çeşitler arasındaki farklılığın, genellikle önemli çıkması ise çeşitlerin potansiyelleri gereği beklenen bir durum olarak algılanmıştır. Özellikle, meyve kalite kriterleri yönüyle çeşitler arasındaki farkların tüm yıllarda önemli olması ve farklılık gruplandırmasında yılların tamamında çeşitlerin grup sıralarının hemen hemen aynı olması, çeşit özelliklerinden kaynaklanan bir durum olarak algılanmıştır.
Yılların ortalaması olarak; en yüksek ağaç gelişim değeri ve ağaç başına düşen en yüksek meyve verimi GD çeşidinden, birim gövde en kesitine düşen en yüksek verim GD ve $\mathrm{SD}$ çeşitlerinden ve birim taç hacmine düşen en yüksek verim SD çeşidinden elde edilmiştir. Tüm yıllar ve yılların ortalaması için en yüksek asitlik değerleri GS çeşidinden, en düşük asitlik değerleri ise SD çeşidinden elde edilmiştir. En yüksek SÇKM değerleri, tüm yıllar ve yılların ortalaması için GD çeşidinden elde edilmiştir. En yüksek sertlik değerleri, tüm yıllar ve yılların ortalaması için GS çeşidinden elde edilmiştir. Su kullanım etkinliği ve sulama suyu kullanım etkinliği, sulama suyu arttıkça azalmıştır. Çeşitlerin tamamında en yükssek su kullanım etkinliği ve sulama suyu kullanım etkinliği S4 sulama programından elde edilmiştir. Sulama programlarının verim ve kalite üzerine etkileri önemsiz ve dolayısıyla suyun etkin kullanımı önemli olduğu için, su kullanım etkinliği en yüksek olan S4 sulama programının uygulanmasının uygun olacağı kanaatine varılmıştır.

\section{Teşekkür}

Bu çalışma, Gıda, Tarım ve Hayvancılık Bakanlığı, Tarımsal Araştırmalar ve Politikalar Genel Müdürlüğü tarafından desteklenen, TAGEM /BB/ 98220K02 no 'lu araştırma projesi sonuç raporundan kısmen özetlenmiştir. Projedeki katkılarından dolayı tüm kişi ve kuruluşlara teşekkür ederiz.

\section{Kaynaklar}

Çelik M (1988). Ankara Koşullarında Williams, Ankara Akça Ve Şeker Armut Çeşitleri İçin En Uygun S.Ö. Ayva Anaçlarının Seçimi Üzerine Bir Araştırma. Ankara Üniversitesi Ziraat Fakültesi Yayınları: 1075, Bilimsel Araştırma ve İncelemeler: 578, Ankara

Doorenbos J \& Kassam A H (1988). Yield response to water: FAO Irrigation and Drainage Paper, No: 33, Rome

Fereres E \& Goldhamer D A (1990). Deciduous fruit and nut trees. In: B A Steward \& D R Nielsen (Eds). Irrigation of Agricultural Crops. Agronomy 30. Published by ASA, CSSA \& SSA, Madison, Wisconsin, pp. 987-1017 
Günbatılı F \& Demirören T (1980). Tokat-Kazova Koşullarında Elmanın Su Tüketimi, Köy Hizmetleri Tokat Araştırma Enstitüsü Yayınları: 37, Tokat

Güngör H \& Kanburoğlu S (1978). Orta Anadolu Koşullarında Elmanın Su Tüketiminin Tarla Parsellerinde Saptanması. Eskişehir Bölge Topraksu Araştırma Enstitüsü Müdürlüğü Yayınları, Genel Yayın No: 143, Rapor Yayın No: 103, Eskişehir

Güngör Y \& Yıldırım O (1989). Tarla Sulama Sistemleri. Ankara Üniversitesi Ziraat Fakültesi Yayınları: 1155, Ankara

Karaçalı İ (2006). Bahçe Ürünlerinin Muhafazası ve Pazarlanması. Ege Üniversitesi Ziraat Fakültesi Yayınlar1: 484, İzmir

Kıvanç F (1991). Isparta-Atabey Ovasında Elmanın Su Tüketimi. Köy Hizmetleri Konya Araştırma Enstitüsü Yayınlar1: 142, Konya

Köksal A I (1982). Bazı Elma ve Armut Anaçları ile Bunların Üzerine Aşılı Önemli Kültür Çeşitleri Arasındaki GA ve ABA Benzeri Maddelerin Değişimleri Üzerine Araştırmalar. Ankara Üniversitesi Ziraat Fakültesi Yayınları: 800 (473), Ankara
Köksal A İ, Dumanoğlu H, Güneş N, Yıldırım O \& Kadayıf̧̧ı A (1999). Farklı sulama yöntemleri ve programlarının elma ağaçlarının vejetatif gelişimi, meyve verimi ve kalitesi üzerine etkileri. Turkish Journal of Agriculture and Forestry 23(4): 909-920

Orta A H, Yüksel A N, Akçay M E, Erdem T \& Balcı B (2001). Elma ağaçlarının farklı sulama yöntemi ve programları altındaki üretim özelliklerinin belirlenmesi. Uludă Üniversitesi Ziraat Fakültesi Dergisi 15: 99-106

SAS (2007). JMP user's guide. SAS Institute, Cary, NC. (http://www.jmp.com (Erişim tarihi: 14.01.2014)

TOPRAKSU (1978). Bitki Yetiştirme Tekniği Rehberi. Topraksu Genel Müdürlüğü Araştırma Dairesi Yayını, Ankara

Yazar A \& Tekinel O (1989). Modern sulama sistemlerinin karşılaştırılması. Çukurova Üniversitesi Ziraat Fakültesi Dergisi 4(4): 18-19

Yurtsever N (1984). Deneysel İstatistik Metotlar. Köy Hizmetleri Genel Müdürlüğü Toprak ve Gübre Araştırma Enstitüsü Müdürlüğü Yayınları, Genel Yayın No: 121, Teknik Yayın No: 56, Ankara 